\title{
Direction, Panel Height, and Tapping Frequency Affect The Daily Bark Consumption in Hevea Rubber Tapping
}

\author{
DOI: 10.18196/pt.2019.094.58-65
}

\author{
Junaidi*, Atminingsih, and Muhammad Rizqi Darojat \\ Sungei Putih Research Center, Indonesian Rubber Research Institute, \\ PO. Box 1415 Medan 20001, Indonesia \\ *Corresponding author, email: junaidi.sp5@gmail.com
}

\begin{abstract}
Bark consumption is defined as the thickness of sliced bark per time unit. This research, aiming to identify the effects of direction, panel height, and tapping frequency on daily bark consumption, was carried out at Sungei Putih Research Center, North Sumatera and several estates in Lampung (Kedaton, Bergen, and Way Lima) from January to March 2018. The observations involved 15 tapping tasks consisting of GT 1, PB 260, and mixed clones. Bark samples were collected from 10 randomized trees in each task. Tapping direction was distinguished as downward tapping and upward tapping, while panel height was classified into < $50 \mathrm{~cm}, 50-100 \mathrm{~cm}$, and $100-130 \mathrm{~cm}$ in downward tapping and $130-150 \mathrm{~cm}, 150-170 \mathrm{~cm}$, and >170 cm in upward tapping. Tapping frequency effect was investigated in a trial plot using frequency of once in three days (d3), once in four days (d4), once in five days (d5), once in six days (d6), and once in eight days (d8) on the basal panel (BO-2). Bark consumption was measured directly using a digital caliper. The observation result indicated that upward tapping had higher bark consumption than downward tapping. In downward tapping, the lower tapping position, the higher bark consumption would be, whilst in upward tapping, bark consumption increased along with the panel height. Low tapping frequency (d4, d5, d6, and d8) showed higher bark consumption per tapping than d3, yet they had lower cumulative bark consumption per year.
\end{abstract}

Keywords: Tapping direction, Tapping frequency, Hevea brasiliensis, Panel height, Bark consumption

\section{ABSTRAK}

Konsumsi kulit yang dimaksud adalah ketebalan kulit yang disadap per satuan waktu. Penelitian ini bertujuan untuk mengetahui pengaruh arah sadap, ketinggian panel, dan frekuensi sadap terhadap konsumsi kulit harian. Penelitian dilakukan di Kebun Percobaan Balai Penelitian Sungei Putih, Sumatera Utara dan beberapa kebun di wilayah Lampung (Kedaton, Bergen, dan Way Lima) pada bulan Januari - Maret 2018. Pengamatan dilakukan terhadap 15 ancak sadap yang terdiri dari klon GT 1, PB 260, dan klon campuran. Sampel kulit diambil dari sepuluh pohon yang dipilih secara acak pada setiap ancak sadap. Arah sadapan dibedakan menjadi penyadapan ke arah bawah dan penyadapan ke arah atas, sedangkan ketinggian panel dikelompokkan dalam < 50 cm, 50 - 100 cm, dan 100 - 130 cm pada penyadapan ke arah bawah, dan 130 - 150 cm, 150 - 170 cm, dan > 170 cm pada penyadapan ke arah atas. Pengaruh frekuensi sadap diamati pada plot percobaan menggunakan frekuensi sadap tiga hari sekali (d3), empat hari sekali (d4), lima hari sekali (d5), enam hari sekali (d6), dan delapan hari sekali (d8) pada panel bawah (BO-2). Ketebalan irisan diukur menggunakan jangka sorong digital. Hasil pengamatan menunjukkan bahwa penyadapan ke arah atas lebih boros dibanding penyadapan ke arah bawah. Pada peyadapan ke arah bawah, semakin mendekati pertautan okulasi konsumsi kulit semakin meningkat, sedangkan pada penyadapan ke arah atas semakin tinggi panel sadap konsumsi kulit semakin boros. Penyadapan frekuensi rendah (d4, d5, d6, dan d8) memiliki konsumsi kulit per sadap lebih tinggi dibanding d3, namun secara kumulatif konsumsi kulit per tahun lebih hemat.

Kata Kunci: Arah sadap, Frekuensi sadap, Hevea brasiliensis, Ketinggian panel, Konsumsi kulit

\section{INTRODUCTION}

Rubber plant (Hevea brasiliensis Muell Arg.) is mainly cultivated in the tropical regions including Asia, Africa, and South America (Priyadarshan, 2017). The ancestor of the rubber plant is wild species from the Amazon basin in South America. This species can grow vigorously in the tropical regions, which are similar to its native environment. Among the natural rubber producer countries, Southeast Asia region is the largest producer of natural rubber in the world. Indonesia, along with Thailand, Malaysia, and Vietnam, is one of natural rubber

main exporter countries. Other countries producing natural rubber outside Southeast Asia region include India, China, and Sri Lanka.

In Indonesia, rubber is the largest cultivated commodity after palm oil. It is cultivated on a large scale, in monoculture system by private or government companies and small-scale, intercropped in farmer land. The most economical part of this species is the sap, called latex, which is synthesized in laticifer tissue through mevalonate (MVA) and 2-C-methyl-D-erythritol 4-phosphate (MEP) path- 
ways (Chow et al., 2012; Ramos et al. 2019). Latex is harvested by tapping the bark tissue to release the sap, which is then collected and processed to become various products. $H$. brasiliensis has a long lifespan; therefore, rubber harvesting actually can be performed in decades. Nevertheless, rubber plantations used to exploit the rubber plant only last for $20-25$ years. The replanting policy executed is mainly due to yield per area unit that has been lower than the operational cost. The decrease in plant density (Qi et al., 2014) and the high position of tapping panel lead to low yield, below the break-even point. Although $H$. brasiliensis has a bark regeneration ability, tapping too deep will disrupt renewed bark formation, which drives planters to accelerate the replanting program before reaching planned economic lifespan. Michels et. (2012) recommended a panel diagnosis to identify previous harvesting practices and predict the effect of the recent tapping system on the plant economic lifespan. Bark consumption is defined as the thickness of sliced bark per time unit. The thickness of bark sliced at each tapping will influence bark consumption cumulatively. Lacote et. (2013) stated that renewed bark indicated the quality of previous tapping practices. By calculating the average of bark consumption per tapping, the economic lifespan of the plant could be estimated.

Improvident tapping drives to the bark consumption which is higher than the regeneration rate and leads to a complicated effect. For example, one of the factors inducing high tapping panel dryness (TPD) incidence on panel B0-2 (Senevirathna et al., 2007) was due to panel B0-1 which was exploited hastily so that the bark thickness of renewed bark (BI-1), which is related to number of latex vessel, was insufficient for translocating assimilate to panel B0-2. The effort to accelerate bark regeneration is needed to assure the tapping can be performed on renewed bark and extend the economic lifespan. Rahayu et al. (2017) reported that applying a combination of latex stimulant and Polyethylene Glycol (PEG) could increase the growth of renewed bark in PB 260 clone.

Many companies haste the replanting program from the initial plan due to uncontrolled daily bark consumption. The skilled-tapper shortage is one of the obstacles experienced by almost rubber plantations, not only in Indonesia but also in plantation around the world since agricultural sector is not the first choice anymore in the professional world (Kadavil, 2012). The young generation is more interested in working in other industries, which offer better salary and more enticing environment (Chouhan and Bhowmik, 2017). Labor shortage leads to a limited choice of skilled-tapper that makes daily bark consumption uncontrolled. Although scientists have been researching for mechanical tapping machine, yet tapping practices still use manual tapping knife, which fully depends on tapper's skill. Practically, panel position affects tapping easiness so that tappers often complain when tapping on the lower basal panel as well as the higher upper panel.

The recent rubber agribusiness shifts toward low-cost practices. One of the approaches adopted by rubber plantations is applying low-frequency tapping system. This tapping system produces a longer gap between two tapping days and implicates a lower labor necessity. It is suspected that bark surface in low tapping frequency will be drier, then it is necessary to slice the bark a bit thicker than in normal tapping frequency. This hypothesis needs to be proved through scientific observation. This study aimed to identify the effect of panel position, height, and tapping frequency on daily bark consumption. The result will be useful for plantation management to arrange the harvesting system, calculate the plant economic lifespan, and construct the tapper's skill improvement program as well as other cultivation practices. 


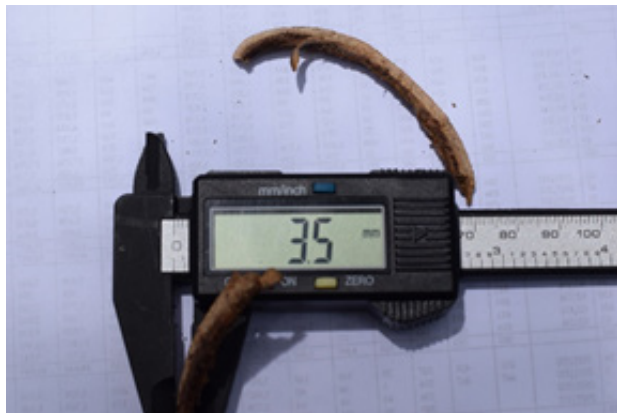

Figure 1. Bark thickness measurement using digital caliper

\section{MATERIALS AND METHODS}

Sample Preparation and Treatment

This study was carried out at Sungei Putih Research Center, Deli Serdang, Sumatera Utara Province and several estates in Lampung Province (Kedaton, Bergen, and Way Lima) from January to March 2018. The observation focused on some factors including tapping direction, panel height, and tapping frequency from 15 tapping tasks consisting of GT 1, PB 260, and mixed clones. Bark samples were collected from 10 randomized trees per tasks with tapping frequency of once in three days (d3). Tapping notation presented in this paper followed the recommendation of (Vijayakumar et al., 2009). Our study distinguished the tapping direction into downward tapping system (panel BO) and the upward tapping system (panel HO). Panel height was measured from the budding intersection and was divided into three categories; downward tapping system in which panel height differed in $<50 \mathrm{~cm}$, $50-100 \mathrm{~cm}$, and $100-130 \mathrm{~cm}$, whilst in upward tapping system was categorized into $130-150 \mathrm{~cm}$, $150-170 \mathrm{~cm}$, and $<170 \mathrm{~cm}$.

\section{Data collection}

Observation on tapping frequency effect was carried out in a trial plot at Sungei Putih Research Center on February - March 2018 using five tapping frequencies, namely once in three days (d3), four days (d4), five days (d5), six days (d6), and eight days (d8). Tapping activity was done using a half spiral on panel BO-2 (35-40 cm from the budding intersection) with the same tapper. In each tapping frequency, daily bark consumption was measured from five trees with three replications. Fresh bark (previously tapped) was measured using digital caliper (Figure 1).

\section{Data analysis}

Analysis of variance (ANOVA) was performed for each factor using $\mathrm{R}$ Statistic Software version 3.4.2 (R Development Core Team) in R Studio Interface version 1.1.383 (R Studio Inc.). Estimated Marginal Means was calculated using emmeans function, while comparison was calculated using the Tukey method with $\alpha=0.05$.

\section{RESULTS AND DISCUSSION}

The Effect of Tapping Direction

Hevea rubber is usually tapped in two stages. The first stage is tapping using a downward tapping system (panel BO) and the next stage is exploitation using an upward tapping system (panel HO) when the basal panel has been completely tapped. Tapping panel management is aimed to assure all panels (bark) can be exploited optimally throughout plant lifespan. (Michels et al., 2012) concluded that the usage of a half spiral downward tapping $(\mathrm{S} / 2)$ and a quarter spiral upward $(\mathrm{S} / 4 \mathrm{U})$ was the best compromise between the yield and economic lifespan of the plant. In our study, upward tapping exhibited higher bark consumption than downward tapping (Figure 2). Upward tapping

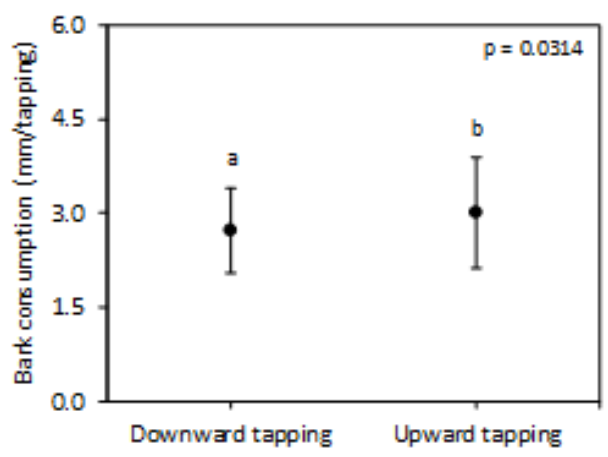

Figure 2. Tapping direction effect on bark consumption. Error bar indicated standard error. The different letter indicated significantly different based on Tukey comparison $(\alpha=0.05)$ 

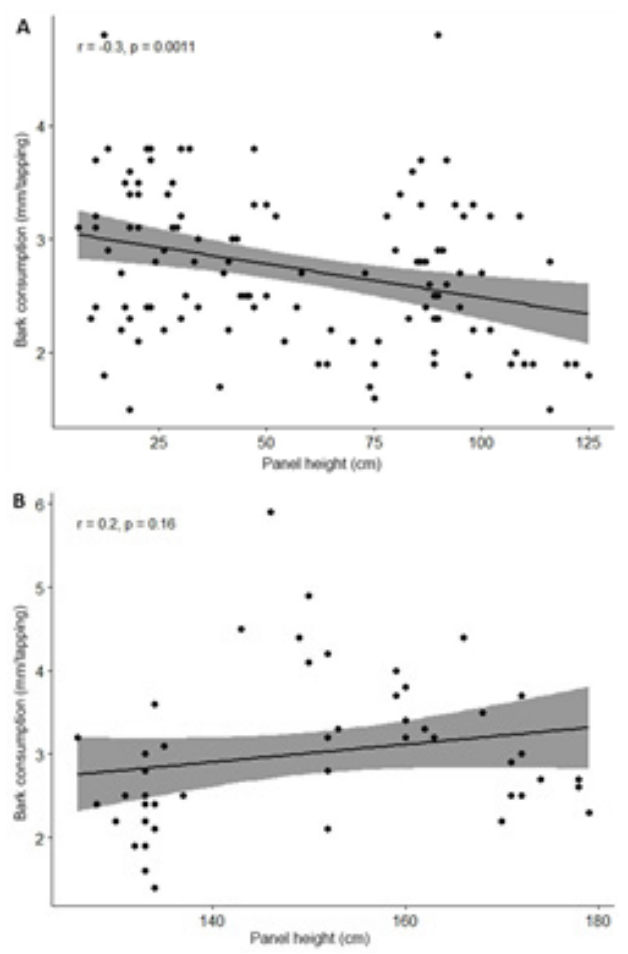

Figure 3. Correlation between panel height with bark consumption on panel $\mathrm{BO}(\mathrm{A})$ and panel $\mathrm{HO}(\mathrm{B})$

consumed $3.01 \mathrm{~mm}$ bark/tapping, while downward used only $2.74 \mathrm{~mm} /$ tapping.

The different level of difficulty of those two tapping directions is suspected to be the main factor causing the discrepancy of the bark consumption. Upward tapping tends to be more difficult than downward tapping. Herlinawati and Kuswanhadi (2012) suggested that besides bark consumption, panel height, slope, and tapping depth should be considered for obtaining the optimum yield. Although the upward tapping system was proven to increase the yield (Obouayeba et al., 2008), uncontrolled bark consumption in this tapping practice might reduce the economic lifespan. Lacote et al. (2004) recommended performing annual change over panel from the basal panel to high panel to avoid physiological fatigue in bark tissue and minimize tapping panel dryness. This alternation also could be adopted to limit bark consumption in high panel through temporary tapping on the basal panel.

\section{The Effect of Panel Height}

Panel height in downward tapping (panel B0) had a significant negative correlation $(\mathrm{r}=-0.3 ; \mathrm{p}$ $=0.0011$ ) with bark consumption. Meanwhile in upward tapping, panel height showed insignificant correlation $(r=0.2, p=0.16)$ with bark consumption. This evidence indicated that the lower the tapping position near the budding intersection, the higher the bark consumption (Figure 3A). Conversely, in upward tapping, the lower the panel position (near $130 \mathrm{~cm}$ ), the lower the bark consumption (Figure 3B).

In downward tapping (panel B0), bark consumption at height $<50 \mathrm{~cm}$ was higher $(2.9 \mathrm{~mm} /$ tapping $)$ than at $100-130 \mathrm{~cm}(2.2 \mathrm{~mm} /$ tapping $)$ but not significantly different from $50-100 \mathrm{~cm}$ of height $(2.6 \mathrm{~cm} /$ tapping $)$ as shown in Figure 4A. Nonetheless, there was no significant difference in bark consumption between panel B0-1 and B0-2 (2.80 $\mathrm{mm} /$ tapping and $2.70 \mathrm{~mm} /$ tapping, respectively)
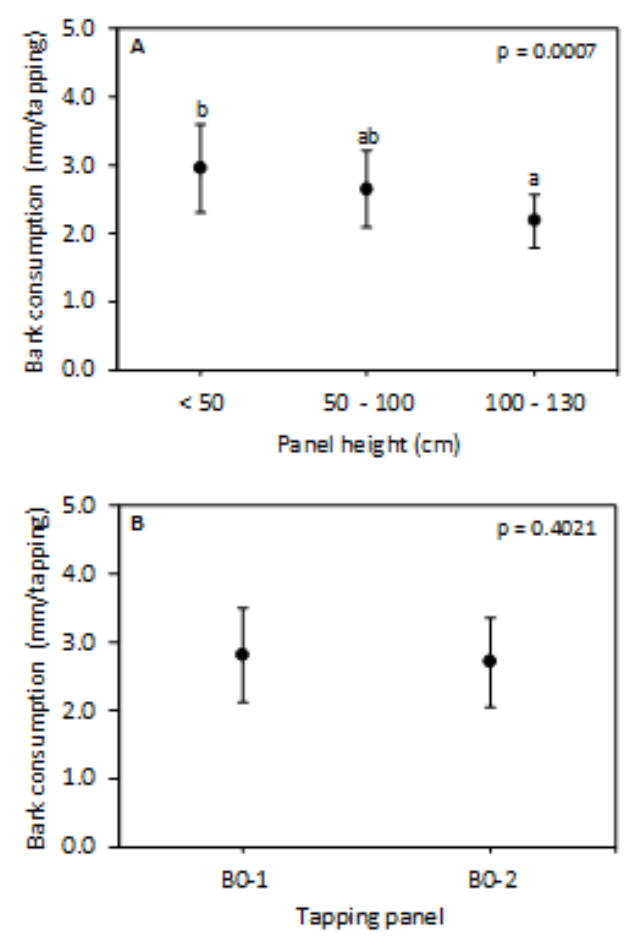

Figure 4. Panel height (A) and tapping panel (B) effects on bark3.5consumption in downward tapping system. Error bar indicated standard error. The different letter indicated significantly different based on Tukey comparison ( $\alpha=0.05$ ) 


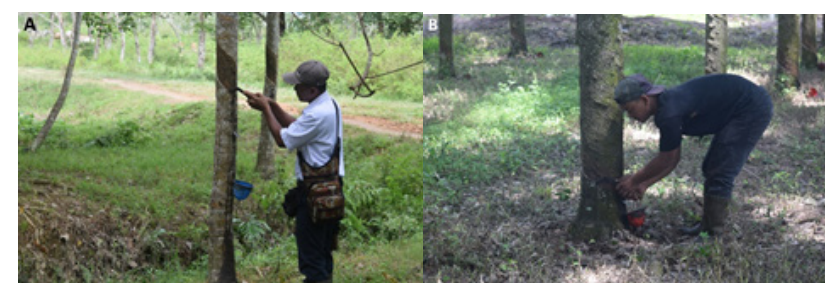

Figure 5. Tapping practice at height $100-130 \mathrm{~cm}(\mathrm{~A})$ and at near budding intersection (B)

as shown in Figure 4B. It showed that in downward tapping, bark consumption was not affected by tapping panel (B0-1 or $\mathrm{B} 0-2)$ neither by the panel height from the budding intersection.

The open tapping is usually conducted at a height of $130 \mathrm{~cm}$ from the budding intersection so that in this study, the trees with panel height of $100-130 \mathrm{~cm}$ were young plants tapped on panel B0-1 or plants that were just moved to panel BO2. Bark consumption in this group was relatively controlled since the position of the tapper was still ergonomic (Figure 5A). Our result indicated that the lower the panel position, the higher the bark consumption although there was no insignificant difference between $100-130 \mathrm{~cm}$ and $50-100 \mathrm{~cm}$. A significant increase in bark consumption occurred when tapping was conducted at $<50 \mathrm{~cm}$. In the condition when tapping panel was near the budding intersection (Figure 5B), tapping activity was more difficult thus bark consumption increased significantly.

In upward tapping system (panel HO), bark consumption was not only influenced by the panel height but also by tapping panel (H0-1 or H0-2). Bark consumption at height of $130-150 \mathrm{~cm}$ was lower $(2.7 \mathrm{~mm} /$ tapping $)$ than at $150-170 \mathrm{~cm}(3.5$ $\mathrm{mm} /$ tapping). Interesting data were found when bark consumption in higher panel position $(>170$ $\mathrm{cm}$ ) showed a decrease to $2.7 \mathrm{~mm} /$ tapping, same consumption rate with $130-150 \mathrm{~cm}$ panel group (Figure 6A). Our result was not in accordance with (Siagian, 2017) who reported that bark consumption in upward tapping system was directly propor-
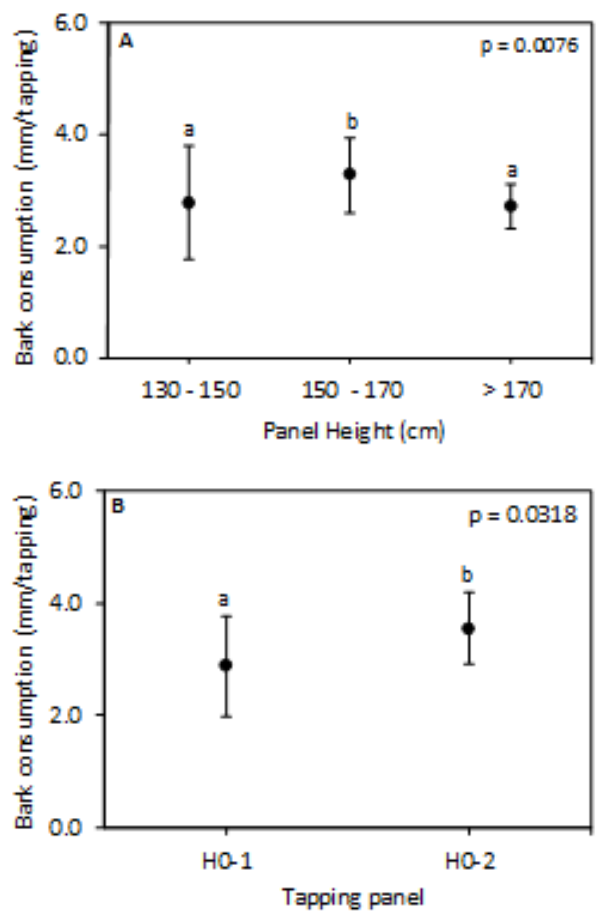

Figure 6. Panel height $(A)$ and tapping panel $(B)$ effects on bark consumption in upward tapping system. Error bar indicated standard error. The different letter indicated significantly different based on Tukey comparison $(\alpha=0.05)$

tional with panel height. When a comparison was performed between bark consumption on panel HO-1 with panel B0-2, there was evidence that HO-2 had higher bark consumption than panel H0-1 (Figure 6B). The average bark consumption on panel H0-1 was $2.88 \mathrm{~mm} /$ tapping, while on panel H0-2 was $3.55 \mathrm{~mm} /$ tapping.

The reachable height of the panel was the key factor to maintain bark consumption. Plants with panel height of $130 \mathrm{~cm}-150 \mathrm{~cm}$ could be relatively easy to tap using a short upward tapping knife (Figure 7A). This position usually occurred in a plant that has just been moved from panel $\mathrm{B} 0-2$ to H0-1 or from H0-1 to H0-2. In the next years, panel position would shift upward and the bark consumption would increase. In this study, we found that the bark consumption at height $>170$ $\mathrm{cm}$ was not different with that at $130-150 \mathrm{~cm}$ as tapper extended the stick to reach higher panel (Figure 7B). 


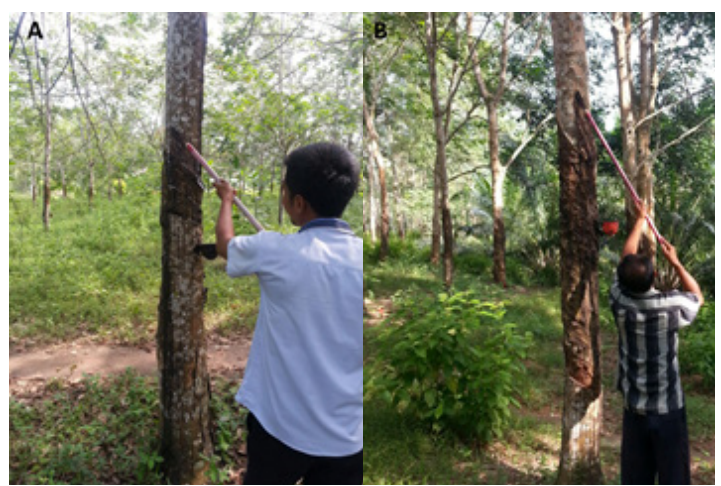

Figure 7. Upward tapping using short-stick knife (A) and longstick knife (B)

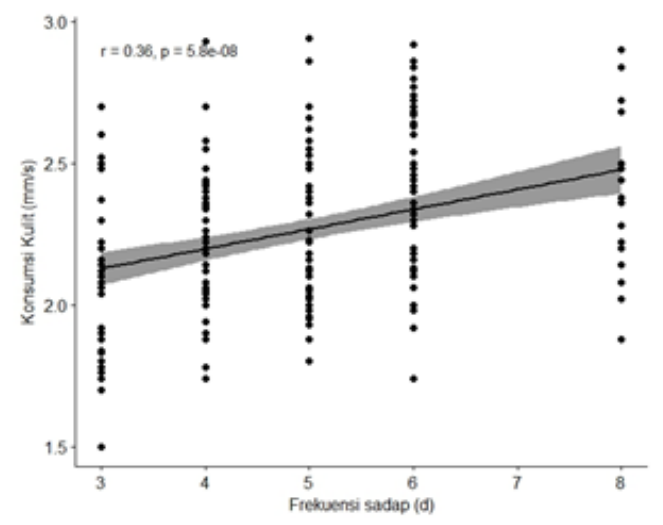

Figure 8. Correlation between tapping frequency and bark consumption

Our result exhibited that bark consumption in panel H0-1 was higher than in panel HO-2. Ideally, the bark consumption should be similar as panel H0-2 used same height with panel H0-1. One of the factors driving higher bark consumption in panel HO-2 was the assumption that plant tapped in H0-2, especially with panel height $>170 \mathrm{~cm}$, would be replanted in a few years so that the bark consumption was less considered. This was an erroneous assumption since bark consumption should be maintained in order to reach the initial-planned economic lifespan. If well-maintained, upward tapping could produce high yield until the panel reached $3 \mathrm{~m}$ of height (Xiaodi et al., 2008).

\section{The Effect of Tapping Frequency}

Tapping frequency is defined as how often the plants are tapped. Our study exhibited a positive correlation $(\mathrm{r}=0.36 ; \mathrm{p}=<0.001)$ between tapping frequency and daily bark consumption (Figure 8). However, our further investigation indicated that a significant difference occurred only in $\mathrm{d} 3$ tapping frequency, while $\mathrm{d} 4, \mathrm{~d} 5, \mathrm{~d} 6$, and $\mathrm{d} 8$ were statistically not different. Our result did not fully support the assumption that the longer the plants are untapped, the thicker the tapping is needed as the bark tissues become drier.

The average of daily bark consumption in $\mathrm{d} 3$ frequency was $2.07 \mathrm{~mm} /$ tapping with annual consumption of $22.8 \mathrm{~cm}$ approximately. Tapping frequency of $\mathrm{d} 4$ had bark consumption of 2.24 $\mathrm{mm} /$ tapping (significantly higher than $\mathrm{d} 3$ ). However, the annual consumption was only $17.9 \mathrm{~mm}$ since it used 80 tapping days per year. Furthermore, tapping frequency $\mathrm{d} 5, \mathrm{~d} 6$, and $\mathrm{d} 8$ had insignificant bark consumption per tapping compared to $\mathrm{d} 4$ but had lower annual bark consumption (Table 1). Our result was in contrary with Kudaligama et al. (2010) who reported that there was no significant difference between $\mathrm{d} 2, \mathrm{~d} 3, \mathrm{~d} 4$ and $\mathrm{d} 6$ with bark consumption around $1.4-1.6 \mathrm{~mm} /$ tapping.

The recent trend in rubber exploitation is adopting a low-frequency tapping system to reduce labor cost consequently to the low rubber price in recent years. This study indicated that low-tapping frequency application would increase daily bark consumption, while annual consumption would be lower as it used less tapping day per year. Sainoi

Table 1. The average of daily and estimation of annual bark consumptions of each tapping frequency

\begin{tabular}{cccc}
\hline $\begin{array}{c}\text { Tapping } \\
\text { Frequency }\end{array}$ & $\begin{array}{c}\text { Daily bark } \\
\text { consumption } \\
\text { (mm/tapping) }\end{array}$ & $\begin{array}{c}\text { Annual } \\
\text { tapping day } \\
\text { (day) }\end{array}$ & $\begin{array}{c}\text { Annual bark } \\
\text { consumption } \\
\text { (cm/year) }\end{array}$ \\
\hline $\mathrm{d} 3$ & $2.07+0.27 \mathrm{a}$ & 110 & 22.8 \\
$\mathrm{~d} 4$ & $2.24+0.24 \mathrm{~b}$ & 80 & 17.9 \\
$\mathrm{~d} 5$ & $2.27+0.27 \mathrm{~b}$ & 62 & 14.1 \\
$\mathrm{~d} 6$ & $2.38+0.26 \mathrm{~b}$ & 50 & 11.9 \\
$\mathrm{~d} 8$ & $2.38+0.27 \mathrm{~b}$ & 35 & 8.3 \\
\hline
\end{tabular}

Note: The different letter in the same column indicated significantly different based on Tukey comparison ( $\alpha=0.05)$ 
et al., (2017) suggested that low tapping frequency applied consistently had potential impacts not only the labor-saving but also a longer economic lifespan. Furthermore, Adou et al. (2017) recommended the $\mathrm{d} 4$ tapping system based on yield and bark consumption considerations.

\section{CONCLUSION}

The daily bark consumption in rubber tapping was influenced by many factors. Upward tapping consumed higher bark than downward tapping system. Panel height drove the tapping easiness and determined bark consumption rate. In downward tapping system, the lower tapping panel would consequence higher bark consumption. Conversely, in upward tapping system, bark consumption increased along with panel height. Another factor affecting bark consumption was the tapping frequency. Low-frequency tapping $(\mathrm{d} 4, \mathrm{~d} 5$, d6, and d8) tended to have higher daily bark consumption compared to a normative frequency (d3). However, the bark consumption was annually low along with the lower number of tapping day per year.

\section{REFERENCES}

Adou, Y. B. C., Atsin, O. J. G., Essehi, J.-L., Ballo, K. E., Soumahin, F. E., Obouayeba, P. A., ... Obouayeba, S. (2017). Latex micro diagnosis, modern management tool of rubber plantations of clones with moderate metabolism GT 1, RRIC 100 and BPM 24. Journal of Applied Biosciences, 121, 12098-12109. https://doi.org/ https://dx.doi.org/10.4314/jab.v121i1.1

Chouhan, P., \& Bhowmik, I. (2017). Labour market conditions of natural rubber plantations in Tripura: an Inquiry. Social Change and Development, 14, 55-69. Retrieved from https://www.okd. in/downloads/jr_17_july/article-5.pdf

Chow, K. S., Mat-Isa, M. N., Bahari, A., Ghazali, A. K., Alias, H., Mohd.-Zainuddin, Z., ... Wan, K. L. (2012). Metabolic routes affecting rubber biosynthesis in Hevea brasiliensis latex. Journal of Experimental Botany, 63(5), 1863-1871. https:// doi.org/10.1093/jxb/err363

Herlinawati, E., \& Kuswanhadi. (2012). Beberapa aspek penting pada penyadapan panel atas tanaman karet. Warta Perkaretan, 31(2), 66-74. https://doi.org/10.22302/ppk.wp.v31i2.268
Kadavil, T. G. (2012). Tapping Labour Shortage and Dilemmas in Policy Options: The Case of Rubber Smallholder Sector in Kerala. Kottayam, India: Rubber Research Institute of India. https://doi.org/10.2139/ssrn.2410142

Kudaligama, K. V. V. S., Rodrigo, V. H. L., Fernando, K. M. E. P., \& Yapa, P. A. J. (2010). Response of low frequency harvesting systems of rubber under drier climatic conditions in Sri Lanka. In Proceedings of the 15th International Forestry and Environment Symposium, University of Sri Jayewardenepura. Sri Lanka, 26-27 November 2010 (pp. 62 - 69). Retrieved from http:// journals.sjp.ac.lk/index.php/fesympo/article/view/163/70

Lacote, R., Doumbia, A., Obouayeba, S., \& Gohet, E. (2013). Tapping panel diagnosis, decision support tool for more sustainable rubber tapping system. IRRDB-MRPPA International Workshop on The Development of Smallholder Rubber Industry in Myanmar. https://doi.org/10.13140/RG.2.1.3148.7527

Lacote, R., Obouayeba, S., Clement-Demange, A., Dian, K., Gnagne, M., \& Gohet, E. (2004). Panel management in rubber (Hevea brasiliensis) tapping and impact on yield, growth, and latex diagnosis. Journal of Rubber Research, 7(3), 199-217.

Michels, T., Eschbach, J. M., Lacote, R., Benneveau, A., \& Papy, F. (2012). Tapping panel diagnosis, an innovative on-farm decision support system for rubber tree tapping. Agronomy for Sustainable Development, 32(3), 791-801. https://doi.org/10.1007/ s13593-011-0069-2

Obouayeba, S., Soumahin, E. F., Boko, A. M. C., Dea, G. B., Dian, K., \& Gnagne, Y. M. (2008). Improvement of productivity of rubber trees in smallholding by the introduction of upward tapping in the south-east of Cote d'Ivoire. Journal of Rubber Research, 11(3), 163-170.

Priyadarshan, P. M. (2017). Biology of hevea rubber. Springer International Publishing. https://doi.org/10.1007/978-3-31954506-6

Qi, D., Zhou, J., Xie, G., \& Wu, Z. (2014). Studies on rubber (Hevea brasiliensis) trees exist plant type after planting and available tapping tree of rubber plantation in China. American Journal of Plant Sciences, 5, 3017-3021. https://doi.org/http://dx.doi. org/10.4236/ajps.2014.520318

Rahayu, M. S., Siregar, L. A. M., Purba, E., \& Tistama, R. (2017). Effect of renewable bark stimulant and PEG on renewable bark growth and rubber production (Hevea brasiliensis) Clone PB 260. International Journal of Science and Research Methodology, 7(1), 71-83. Retrieved from http://ijsrm.humanjournals. com/wp-content/uploads/2017/08/6.MURNI-SARI-RAHAYULUTHFI-A.M.-SIREGAR-EDISON-PURBA-RADITE-TISTAMA.pdf

Ramos, M. V., Demarco, D., da Costa Souza, I. C., \& de Freitas, C. D. T. (2019). Laticifers, latex, and their role in plant defense. Trends in Plant Science, 24(6), 553-567. https://doi.org/10.1016/j. tplants.2019.03.006

Sainoi, T., Sdoodee, S., Lacote, R., \& Gohet, E. (2017). Low frequency tapping systems applied to young-tapped trees of Hevea brasiliensis (Willd. ex A. Juss.) Müll. Arg. in Southern Thailand. Agriculture and Natural Resources, 51(4), 268-272. https:// doi.org/10.1016/J.ANRES.2017.03.001 
Senevirathna, A. M. W. K., Wilbert, S., Perera, S. A. P. S., \& Wijesinghe, A. K. H. S. (2007). Can tapping panel dryness of rubber (Hevea brasiliensis) be minimised at field level with better management? Journal of the Rubber Research Institute of Sri Lanka, 88, 77-87. https://doi.org/10.4038/jrrisl.v88i0.1819

Siagian, N. (2017). Teknologi Memanen Lateks pada Tanaman Karet untuk Mewujudkan Produktivitas Tinggi. Yogyakarta: Lembaga Pendidikan Perkebunan.

Vijayakumar, K. R., Gohet, E., Thomas, K. U., Xiaodi, W., Sumarmadji, Rodrigo, L., ... Said, M. A. M. (2009). Special communication: Revised international notation for latex harvest technology. Journal of Rubber Research, 12(2), 103-115. Retrieved from https://www.researchgate.net/publication/261141330_Revised_International_Notation_for_Latex_Harvest_Technology Xiaodi, W., Xianzhou, X., Shiqiao, L., L, S., \& Ming, W. (2008). Upward tapping in China. In Conference paper, IRRDB Workshop: Latex Harvesting Technologies, Kuala Lumpur 5 - 8 Mei 2008. Kuala Limpur: International Rubber Research and Development Board. 